\title{
Functional and technological properties and methods of introduction of grain raw materials in the manufacture of meat and vegetable products
}

\author{
Oksana Evdokimova ${ }^{1}$, Vladimir Masalov ${ }^{1}$, Tamara Ivanova ${ }^{2}$ and Yoshaa Ibrahim ${ }^{2,3}$ \\ ${ }^{1}$ Orel State Agrarian University tamed after N V Parakhin, 69, Generala Rodina Street, Orel, 302019, Russia \\ ${ }^{2}$ Orel State University named after I S Turgenev, 95, Komsomol'skaya street, Orel, 302026, Russia \\ ${ }^{3}$ Damascus University, Faculty of Agricultural Engineering, Food Science, Syria
}

\begin{abstract}
Currently, it is possible to ensure the protein balance in food only when combining plant and animal proteins. The functional and technological properties and methods of introducing non-meat ingredients (meal and grain raw materials) in the production of meat and vegetable pates are investigated. The influence of the degree of grinding of cereals on the viscosity properties of flour that has undergone hydrothermal treatment is studied. A direct dependence of the maximum value of the loading force on the degree of grinding of cereals is established, with an increase in the degree of grinding of cereals, the strength characteristics increase. The water-retaining capacity (WRC) of flour proteins was studied, so deodorised non-fat soy flour has the least ability to bind water, with a hydromodule of $1: 1.75,6.1 \%$ of water is separated, with a hydromodule of $1: 2.25$, buckwheat groats did not bind only $6.6 \%$ of water. Flour from cereal oat flakes, separation of non-cohesive water $(8.5 \%)$ with a hydromodule of $1: 2.5$, with an increase in the hydromodule to $1: 3$, there is a slight decrease in this indicator by $7.5 \%$. The fat module has a weak effect on the FRC of the flour samples being studied. Flour from cereals has a lower FRC, with fat modules (1:0.5) FRC does not change significantly and is from 0.44 to $0.45 \mathrm{~g}$ of oil per $1 \mathrm{~g}$ of flour, and for deodorised non-fat soy flour it is $100 \%$. The mathematical description of the process of absorption of water and fat by flour from cereals and soy flour showed a steady decrease in WRC and an increase in WRC with an increase in hydro-and fat modules.
\end{abstract}

\section{Introduction}

Taking into account the forecast of the global supply of the Earth's population with proteins, in modern conditions, ensuring the protein balance in food can only be achieved by combining plant and animal proteins. Therefore, many scientists are working on the development of new types of meat products, including those treated with ionizing radiation, with the use of dihydroquercetin in order to increase the stability of the properties of ghee in meat products, and their introduction to the consumer market [1-10].

We have conducted research on the functional and technological properties and methods of introducing meal and grain raw materials-soy flour and flour from cereals, which are non-meat ingredients and are of interest in the production of meat and vegetable pates. The carbohydrate part of cereals is represented by starch and mono-and disaccharides, fiber, the protein content in flour from cereals is up to $11.5 \%$, in soy flour up to $36.5 \%$ (Fig. 1).

To study the compatibility of non-meat ingredients introduced into the pate recipes, the influence of the degree of grinding of cereals on the rheological, in particular on the viscosity properties of flour that has undergone hydrothermal treatment, was studied.

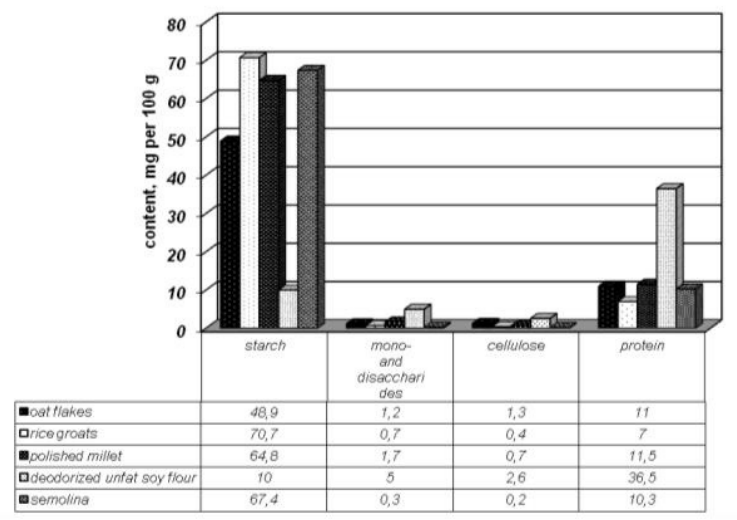

Fig.1. Protein and carbohydrate content in soy and grain raw materials

Four types of cereals were studied: buckwheat groats (GOST 5550 - 74), rice groats (GOST 6292-93), millet groats (GOST $572-60$ ) and oat flakes (GOST 21149 93). Grinding of all types of cereals was carried out on a laboratory hammer crusher Z A13 - MIZZ-24 (Budapest), designed for grinding grain. After grinding, the grains were sieved on an A-20 analyzer designed for dry sieving 
of bulk materials into a number of particle size classes using vibrating screens with a cell size, mm: $1.2 ; 0.9$; 0.315 . The resulting flour was subjected to hydrothermal treatment with the hydromodule water: groats $2: 1$. The resulting semi-finished product had a gelatinous consistency with a mass fraction of dry substances of $34.8 \pm 0.5 \%$. The measurements were carried out on the device "Structurometer".

\section{Equations and mathematics}

As a result of the experiment, a direct dependence of the maximum value of the loading force on the degree of grinding of cereals was established. Thus, with an increase in the degree of grinding of oat flakes (from a sieve of $1.2 \mathrm{~mm}$ to a sieve of $0.315 \mathrm{~mm}$ ), there is an increase in the maximum value of the loading force from $30.25 \mathrm{~g}$ to $37.0 \mathrm{~g}$, respectively. This tendency to increase the maximum loading force can be traced in all the studied semi-finished cereals.

A significant influence on the resulting structure of cereals that have undergone hydrothermal treatment is exerted by starch, which occupies the first place among carbohydrates in terms of its quantitative content. The ability of starch to swell and form jelly is of great technological importance and significantly affects the quality of meat-containing products under temperature exposure.

It is established that the indicators of the maximum value of the loading force of the studied cereals subjected to hydrothermal treatment are directly proportional to the degree of grinding, i.e., with an increase in the degree of grinding of cereals, the strength characteristics increase.

At the second stage, we investigated the functional and technological properties of flour from cereals and non-fat deodorized soy flour produced by Kubanmelprod Ltd. The flour contained $43.2 \%$ protein and $24.9 \%$ lipids.

In the study of the functional properties of flour, the methods used for soy protein preparations were used. The water-restraining capacity (WRC) of flour proteins affects the moisture content in pates, which determines the consistency and yield of the finished product. As you know, the main proteins of soy and cereals are albumins and globulins.

The water-holding capacity of the flour also depends on the presence of starch in the flour. The starch content in soy is not high - about $10 \%$, in flour from cereals the starch content is much higher and is in buckwheat up to $60.7 \%$, in millet up to $64.8 \%$, in oat flakes up to $48.9 \%$.

For the experiment, 8 variants of hydromodules were prepared with the ratio (\%by weight) flour : water from 1 : 1.25 to $1: 3.0$ with a water mass interval of 0.25 , soy deodorized non-fat flour has the lowest percentage of separated water - 6.1-with a hydromodule of $1: 1.75$. (Table 1).

Table 1. Water holding capacity of flour processing products, $\%$ of separated water.

\begin{tabular}{|c|l|l|l|l|l|l|l|l|}
\hline \multirow{2}{*}{ Flour } & \multicolumn{7}{|c|}{ Hydromodule (water: raw material) } \\
\cline { 2 - 8 } samples & $1:$ & $1:$ & $1:$ & $1:$ & $1:$ & $1:$ & $1:$ & $1:$ \\
& & 1.5 & 1.75 & 2.0 & & 2.5 & & 3.0 \\
\hline
\end{tabular}

\begin{tabular}{|l|l|l|l|l|l|l|l|l|}
\hline & $\mathbf{1 . 2}$ & $\mathbf{5}$ & & & $\begin{array}{l}\mathbf{2 . 2} \\
\mathbf{5}\end{array}$ & & $\mathbf{2 . 7}$ & $\mathbf{5}$ \\
\hline $\begin{array}{l}\text { Soy flour, } \\
\text { deodorize } \\
\text { d, not fat- } \\
\text { free }\end{array}$ & 0 & 0 & 6.1 & 24.1 & 36.4 & 47.0 & 56.2 & $\begin{array}{c}65 . \\
7\end{array}$ \\
\hline $\begin{array}{l}\text { Buckwhea } \\
\text { t flour }\end{array}$ & 0 & 0 & 0 & 0 & 6.6 & 22.1 & 34.2 & $\begin{array}{c}43 . \\
7\end{array}$ \\
\hline $\begin{array}{l}\text { Flour from } \\
\text { millet } \\
\text { groats, } \\
\text { ground }\end{array}$ & 0 & 0 & 0 & 3.4 & 16.4 & 27.6 & 38.2 & 45. \\
\hline $\begin{array}{l}\text { Flour from } \\
\text { cereals oat } \\
\text { flakes }\end{array}$ & 0 & 0 & 0 & 0 & 0 & 8.5 & 17.3 & $\begin{array}{c}29 . \\
7\end{array}$ \\
\hline
\end{tabular}

The calculated mass fraction of water in the flour inputs researched, which provides the maximum WRC for various hydromodules.

A mathematical description of the process of water and fat absorption by flour is carried out using trend lines, which represents a steady change in the indicator depending on the concentrations of water and fat, which is a deterministic component. It expresses the analytical function on which the forecast estimates are formed.

Non-fat deodorized soy flour has the least ability to bind water, since at the hydromodule $1: 1.75,6.1 \%$ of water is separated.

When module 1:2,25 buckwheat are not tied to only $6.6 \%$ of water, and with the increase of the hydromodule to $1: 3$ MOS cereals declined by $19.5 \%$.

WRC flour from pollished millet cerial is less, since the hydromodule 1:2 flour does not bind to $3.4 \%$ moisture, with the increase of hydromodule to $0.25 \mathrm{~g}$, the amount of free water increased more than $16 \%$.

The greatest WRC of all the analyzed non-meat ingredients is distinguished by flour from cereal oat flakes. Thus, the separation of incoherent water $(8.5 \%)$ is observed only at a hydromodule of $1: 2.5$, with an increase in the hydromodule to $1: 3$, there is a slight decrease in this indicator by $7.5 \%$.

It was found that with the increase in hydromodules, the WRC significantly decreases. So, with a maximum hydromodule of $1: 3$, for deodorised non-fat soy flour, the WRC is lower by $35.6 \%$, for buckwheat flour it is lower by $19.5 \%$; from millet cereals-by $14.5 \%$, from oat flakesby $7.5 \%$.

An important functional and technological property is the fat-restraining capacity (FRC) of the studied samples of grain raw materials in the form of flour. Since the composition of the minced meat of most meat-containing products includes fat-containing raw materials, in particular, semi-fat pork, which improves the taste and nutritional properties of products, as well as their consistency, it was interesting to study the FRC of the studied types of flour. As you know, the fat contained in the recipe, up to a certain limit (up to 20\%) gives meatcontaining products elasticity and tenderness; with an increase in its content, the stickiness increases, the moisture-holding capacity and the quality decreases.

For the determination of FRC, 8 variants of samples with a fat module were also prepared at the ratio (\%by weight) flour: butter from $1: 0.25$ to $1: 2$ with an interval of 0.25 oil weight (Table. 2 ). 
Table 2. Fat-holding capacity of flour processing products, $\%$ of separated oil

\begin{tabular}{|l|l|l|l|l|l|l|l|l|}
\hline \multirow{2}{*}{ Flour } & \multicolumn{7}{|c|}{ fat module (fat: raw material) } \\
\cline { 2 - 8 } & $\mathbf{1 :}$ & $\mathbf{1 :}$ & $\mathbf{1}$ & $\mathbf{1 :}$ & $\mathbf{1}$ & $\mathbf{1 :}$ & $\mathbf{1 :}$ & $\mathbf{1}$ \\
& $\mathbf{0 . 2 5}$ & $\mathbf{0 . 5}$ & $\mathbf{0 . 7 5}$ & $\mathbf{1 . 0}$ & $\mathbf{1 . 2 5}$ & $\mathbf{1 . 5}$ & $\mathbf{1 . 7 5}$ & $\mathbf{2 . 0}$ \\
\hline $\begin{array}{l}\text { Soy } \\
\text { flour, } \\
\text { deodori } \\
\text { zed, not } \\
\text { fat-free }\end{array}$ & 0 & 0 & 10.2 & 24.7 & 31.0 & 42. & 51.0 & 60.1 \\
\hline $\begin{array}{l}\text { Buckwh } \\
\text { eat flour }\end{array}$ & 0 & 13.0 & 17.5 & 24.5 & 29.8 & 33.6 & 37.1 & 40,0 \\
\hline $\begin{array}{l}\text { Flour } \\
\text { from } \\
\text { millet } \\
\text { groats, } \\
\text { ground }\end{array}$ & 0 & 12.0 & 14.9 & 18.0 & 23.6 & 27.6 & 32.0 & 34.7 \\
\hline $\begin{array}{l}\text { Flour } \\
\text { from } \\
\text { cereals } \\
\text { oat } \\
\text { flakes }\end{array}$ & 0 & 10.0 & 16.0 & 22.0 & 28.4 & 30.8 & 33.8 & 36.3 \\
\hline
\end{tabular}

As the results showed, the fat module has a relatively weak effect on the fat content of the flour samples researched. The results of the fat modules, which are refined after recalculation, in which the fat is completely absorbed by the flour, are shown in Fig. 3 .

With a fat modulus of $1: 0.75$, only $0.67 \mathrm{~g}$ of oil binds to $1 \mathrm{~g}$ of non-fat deodorized soy flour; with an increase in the fat modulus to $1: 1.75$, one gram of flour absorbs 0.86 $\mathrm{g}$ of oil. With an increase in the fat module to $1: 2$, the value of the indicator decreases, therefore, deodorized non-fat soy flour has a slight fat content, which is explained by the presence of $30 \%$ fat in it.

Buckwheat flour has the lowest FRC, compared to other types of grain crops studied. With a fat modulus of $1: 0.25$, this flour is able to absorb all the oil, with an increase in the fat modulus to $1: 2$, there is a steady tendency to reduce the fat content by $42.3 \%$

Studies of FRC flour from millet grits have shown that with a fat modulus of 1:0.5, the amount of separated oil is similar to rice flour, but a further increase in the fat modulus from 1:0.75 to 1: 2 leads to an increase in the proportion of separated oil from 12 to 34.7 .

With the fat-module 1:0.5 of oatmeal flour, the amount of bound oil is greater than in other types of the studied cereals by $2.4 \%$, but less than in deodorized nonfat soy flour by $11.1 \%$, with an increase in the fat-module, a decrease in the proportion of bound oil by $36.3 \%$ is observed.

Previously conducted studies of FRC protein preparations showed that they have a FRC of 1.3 to $3 \mathrm{~g}$ of oil per $1 \mathrm{~g}$ of protein [Evdokimova, O. V. Methods of determination]. Flour from cereals has a lower FRC, and with the same fat modules (1:0.5) FRC does not change significantly and is from 0.44 to $0.45 \mathrm{~g}$ of oil per $1 \mathrm{~g}$ of flour, and for deodorized non-fat soy flour it is $100 \%$.

An increase in the fat module does not equally affect the increase in the fat content of different types of flour. With an increase in the fat module (from 1:0.75 to 1:2) The fat content of non-fat deodorized soy flour increases slightly (from 0.67 to $0.8 \mathrm{~g}$ of oil per $1 \mathrm{~g}$ of flour), which is explained by the presence of about $30 \%$ fat in soy flour. However, this indicator is for flour from different types of cereals (with fat modulus 1:2) increases by $150-160 \%$ and is from 1.15 to $1.3 \mathrm{~g}$ of butter per $1 \mathrm{~g}$ of flour. In addition to proteins, carbohydrates - starch and fiber-can also have adsorption properties in relation to fats.

\section{Conclusion}

Thus, the mathematical description of the process of absorption of water and fat by flour from cereals and soy flour showed a steady decrease in WRC and an increase in FRC with an increase in hydro-and fat modules; the highest FRC is flour from cereal millet ground at a hydromodule of $1: 1.2$; for the analyzed samples of flour from cereals, the FRC is lower than the WRC and slightly differs depending on the type of flour; the mass fraction of fat that provides the maximum FRC is $0.86-0.13 \mathrm{~g}$ of fat per $1 \mathrm{~g}$ of flour.

\section{References}

1. Dependence of electron paramagnetic resonance (EPR) spectrum parameters on the kind of meat and fish treated by ionizing radiation Timakova, R.T., Tikhonov, S.L., Evdokimova, O.V., Butenko, I.V.Gigiena i Sanitariya, 97(9), p. 873-876 (2018)

2. Effect of dihydroquercetin on the stability of the properties of rendered fats / N N Shagaeva1, I A Zachesova1, S V Kolobov2 and O V Evdokimova / IOP Conference Series: Earth and Environmental Science, Volume 640, International Conference on Production and Processing of Agricultural Raw Materials 26-29 February 2020, Voronezh, Russian FederationCitation N N Shagaeva et al 2021 IOP Conf. Ser.: Earth Environ. Sci. 640042019

3. Lucas-Gonzalez R., Perez-Alvarez J., Viuda-Martos M., Fernandez-Lopez J. Pork liver pate enriched with persimmon by-products: the effect of gastrointestinal digestion in vitro on the stability of the fatty acid and polyphenol profile. Nutrients .
2021;
13
(4):
1332.https:

//doi.org/10.3390/nu13041332

4. Skalecki, Petr, Agnieszka Kalinyak-Dzyura, Petr Domaradski, Mariusz Florek, Eva Poleshak and Malgorzata Dmoch. 2021. "The effect of replacing pork with fish products on the content of fatty acids, physicochemical and sensory properties of pork pate" Applied Sciences 11, no. 1: 188.https: //doi.org/10.3390/app11010188

5. Bianchin, Mirelli, Diane Pereira, Jacqueline D.F. Almeida, Christian D. Moura, Rafaelli S. Piñeiro, Leila F. S. Heldt, Charles V. I. Haminuk and Solange T. Karpes, 2020. "Antioxidant properties of lyophilized rosemary and sage extracts and their effect on the prevention of lipid oxidation in avian birds "Molecules 25, no. 21: 5160.https: //doi.org/10.3390/molecules25215160 
6. Poznyakovskiy V.M., Gorlov I.F., Tikhonov S.L., Shelepov V.G. About the quality of meat with PSE and DFD properties / Foods and Raw Materials. T. 3. № 1. p. 104-110 (2015)

7. Timakova R.T., Tikhonov S.L., Tikhonova N.V., Poznyakovskiy V.M. Use of the method of electron paramagnetic resonance for determination of absorbed of doses of ionizing radition of different types of meat and fish raw materials / Foods and Raw Materials. T. 5. № 2. p. 162-169 (2017)

8. N.A. Berezina, A.V. Artemov, I.A. Nikitin, A.A. Budnik International Journal of Advanced Computer Science and Application, 10, 137 (2019)

9. Bigliardi, B. Innovation trends in the food industry: Thecase of functional foods / B. Bigliardi,F. Galati// Trends in Food Science \& Technology. - 2013. Vol. 31, №2. - P. 118-129. - Mode of access: https://www.researchgate.net/publication/25734626 4_Innovation_trends_in_the_food_industry_The_c ase_of_functional_foods

10. Lairon, D. Nutritional quality and safety of organic food. Overview / D. Lairon // Environmental assessment . - 2011. - № 2. - C. 74-92. 